\title{
Problem Focused Coping Methods Used by Students During Covid-19
}

\section{Ahmad Muhammad Diponegoro*, Ayu Meryka Santoso, Endah Siti Nurjannah, Naufan Rizqianto Diastu, Khaidir Ali, Yolanda Fidyawaty, Gladis Corinna Marsha, and Een Rohaeni}

Psychology Master of Science, Ahmad Dahlan University, Yogyakarta, Indonesia

\section{Abstract}

The widespread transmission of the Covid-19 virus has heightened stress and anxiety levels for many people around the world. This study focuses on the ways in which students are using problem-focused coping mechanisms. The study uses 6 research subjects, chosen via a purposive sampling technique, who were taking online lectures. The results of this study indicate that all subjects adopted similar coping mechanisms regarding health protocols, however the study also indicated a disparity in subject awareness of appropriate health protocols.

Corresponding Author:

Ahmad Muhammad Diponegoro

ahmad.diponegoro@psy.

uad.ac.id

Published: 5 January 2021

Publishing services provided by Knowledge E

\section{(c) Ahmad Muhammad}

Diponegoro et al. This article is distributed under the terms of the Creative Commons

Attribution License, which permits unrestricted use and redistribution provided that the original author and source are credited.

Selection and Peer-review unde the responsibility of the ICoPsy Conference Committee.

\section{G OPEN ACCESS}

Keywords: corona virus, covid 19, problems focused coping

\section{Introduction}

COVID-19 (coronavirus disease2019) is a disease caused by a new type of coronavirus, namely Sars-CoV-2, which was first reported in Wuhan China on December 31, 2019 (Mohsin, Hongzhen, Sume, \& Hussain, 2020). COVID-19 can cause symptoms of acute respiratory problems such as fever above $38^{\circ} \mathrm{C}$, cough and shortness of breath for humans, besides that it can be accompanied by weakness, muscle aches, and diarrhea. In people with severe COVID-19, it can cause pneumonia, acute respiratory syndrome, kidney failure and even death. The novel virus (referred to as "severe acute respiratory syndrome corona-virus 2", or "SARS-CoV-2") that emerged in late 2019 waspreviously unknown to humans, highly infectious, and, withno human immunity, spread globally over several months (Bell et al., 2020).

COVID-19 poses considerable threats to people's health, lives, and economy in many countries (Umucu \& Lee, 2020). The Covid-19 virus pandemic has caused many problems in various aspects of human life, such as religious, economic, social and political (Johnson, Johnson, Webber, \& Nettle, 2020), cultural and lifestyle life. As the spread of Coronavirus Disease 2019 (COVID-19) has led to statewide emergency declarations 
and social distancing man-dates, concerns have been raised over the possibility that the positive effects of social distancing for older adults' health may be offset by the potentially health-exacerbating consequences of lone-liness. Although loneliness can have large negative effects on the physical, cognitive, and psychological health of older adults, lone-liness during COVID-19 may have an even larger effect on ado-lescent and young adult populations (Beam \& Kim, 2020). Adverse childhood experiences, which is defined by different forms of abuse, neglect, and household dysfunction occurring before the age of 18 years, is a major public health problem in the United States that has the potential to worsen in the current COVID-19 pandemic (Bryant, Oo, \& Damian, 2020).

Especially in the field of psychology, this pandemic wave has a very significant impact in the field of human mental health. COVID-19 affects the mental health of the population dramatically (Ainamani, Gumisiriza, \& Rukundo, 2020; Banerjee \& Bhattacharya, 2020). In a previous study, it was found that several constructs derived from a positive definition of mental health had changed during psychotherapy. It remains unclear whether they change as part of a single process together with symptomatic change, as part of separate processes, or whether a change in one of the variables predicts change in another variable. during psychotherapy in positive characteristics of mental health (e.g., happiness, honesty, playfulness, creativity, and affiliative humor style)(Yonatan-Leus, Shefler, \& Tishby, 2020)stated that "The policy of studying from home, working from home, and worshiping at home needs to be intensified to reduce the spread of Covid-19," said President Joko Widodo. (Kompas, 6 March 2020). This policy is appropriate, although in its journey it creates new problems for the community, both students, workers / employees, and all the people, because all activities must be carried out at home, which is known as Work From Home (WFH) and applies social distancing. In Indonesia or some college was not ready to use learning technology with the online system or online.Changes in learning methods from classical and face-toface methods to methods online get various reactions from students. The short time, the many assignments, the number of quotas, the signal conditions make students find it difficult to prepare everything properly. In addition, it is also known that learning programs online have hidden skills, namely the ability to master technology and use it properly. Even with the implementation of this system, it was found that there were students who were mentally disturbed, stressed and unable to follow the learning process properly.

It is vital to promote coping strategies that are effective and sustainable. It is only then that people will feel able and competent to engage with perhaps one of the 
greatest societal challenges in a generation-COVID-19 (Jaspal \& Nerlich, 2020). In general, stress can be relieved by transacting in an environment in which the transaction relationship is a dynamic process. Coping is conceptualized as conscious efforts to solve the problems created by stressful events that are appraised as exceeding a person's capacity and resources. Coping strategies are differentiated into two types: (a) problem-focused coping, which actively manages specific problems by altering the origin of stress, and (b) emotion-focused coping, which regulates the emotional distress associated with problems (Wong et al., 2016).

Adolescence is a period of transition from childhood to adulthood. It is well established that stressful life experiences predict psychological problems in children and adolescents and that exposure to stress increases during adolescence, contributing to heightened rates of psychological distress during this developmental period (Reife, Duffy, \& Grant, 2020).In a pandemic like this, people cope in various ways. For example, by seeking as much information as possible about COVID-19 regarding directions, appeals and prohibitions in order to avoid the spread of COVID-19, maintaining a healthy diet, adequate rest, regular exercise, maintaining distance in dealing with other people such as not shaking hands, and always using masks when outdoors. Washing hands is also a strategy to reduce the potentially harmful effects of Covid(Trougakos, Chawla, \& McCarthy, 2020). Washing hands is an example of a strategy problem focused coping, where this action leads to efforts to solve the problems that are being faced during the current COVID-19 pandemic. Every individual has the potential to act according to his wishes. However, in social life, individuals must follow certain patterns in accordance with the socio-cultural life of the community. This coping strategy is not based on caring students only for themselves. Instead, this group thinks of others such as their parents and other family members. To overcome COVID-19 cannot be in the short term. There may be a long period of time, as the next wave of COVID may emerge.

Students are a community that is part of society, students must also make various efforts in order to survive in the study process in the midst of the current COVID-19 pandemic situation, which at this time caused many kinds of problems. This is certainly not an easy thing, considering that students have a lot of demands to learn during the COVID-19 pandemic by using media online as a learning tool because they cannot interact directly with lecturers or teachers, besides that students must also maintain their immunity to stay healthy during the COVID-19 pandemic so that they can carry out their activities and obligations as students. Therefore, researchers are interested in discussing the current problem, namely "Problem Focused Coping Among Students During thePandemicCovid-19". 


\subsection{Problem Focused Coping}

There seems to be relatively stronger evidence that problem-focused coping strategies would promote better mental health outcomes and well-being (Aebi, Giger, Platther, Metzke, \& Steinhausen, 2014)whereas emotion-focused coping strategies were regarded as dysfunctional (Taylor \& Stanton, 2007) and might result in mental health problems. Problem focused coping is a form of coping that focuses on problems and tries to solve existing problems, while individuals who use this strategy are individuals who believe they will be able to face or change stressful situations or conditions.Coping, particularly problem-focused (PF) and disengaged (DS) behaviors, offers one plausible pathway by which service members' subclinical trauma symptoms might predict civilian partners' psychological distress(Lovell \& Gaszka, 2018).

Several researches showed that Problem Focused Coping (PFC) basically aims to solve the problem completely and how to deal with stress anxiety effectively and is relatively associated with reduced levels of depressionproblem-focused strategies are expected to moderate the negative effects of the stressor. In the midst of the current pandemic, handwashing is one of the most central forms of problem-focused coping (Trougakos et al., 2020).

\section{Research Methods}

This research uses qualitative research methods using a case study approach. Creswell (Herdiansyah, 2015)states that case studies focus on exploring a system that is interconnected with one another on several matters in a detailed case, accompanied by in-depth data mining using all sources of information that are rich in context. In this study, the study will explore the problem of problem focused coping among students during pandemic covid-19. Data collection is done by means of interviews. The number of subjects in this study was six people, where the subject was taken using purposive sampling technique with the criteria of students who were taking lectures online.

\section{Data analysis and Discussion}

The results of this study support the theoretical concept of 


\subsection{Exercised Caution}

Prudence is characterized by individuals thinking and considering several alternative problem solutions who may be careful in deciding problems and evaluating strategies that have been done before, as well as ask other people's opinions. It also does this by refraining from actions that will do more harm than good, thinking carefully about what to do, and trying not to do something that will be regrettable, but being open to certain things.

The subjects of TA, R, A, N, TR and RI have similarities in terms of protecting themselves from COVID-19 by consciously always being more careful when traveling and being in large crowds. The six subjects always carried a sanitizer or handwashed their hands when entering a new place or returning home. The six subjects also always used masks and obeyed health protocols when going out of the house. Subject A said that he would not travel if it was not an urgent matter.Based on the description above, it can be concluded that the subjects of TA, R, A, N, TR and RI always comply with health protocols such as wearing a mask, carrying a hand sanitizer wherever they go, maintaining distance, and washing hands using soap and running water that has been provided in every place. which they will enter or when they are about to enter the house.

This is in line with research conducted by (Semaraputri, SAKT, \& Rustika, 2018) which found that in solving individual problems with strategy, they problem focused coping will try to make the condition of the problem at hand stable by self-introspection by doing something to fix the problem so that it does not happen again. The results of research (Semaraputri, SAKT, \& Rustika, 2018) can be seen in the aspect of exercised caution in TA, R, A, N, TR and RI subjects, where they take preventive measures against COVID-19 by adhering to health protocols such as washing hands, wearing masks, carrying hand sanitizer and keep a distance from large crowds. These precautions are taken to avoid exposure to COVID-19 and help to break the chain of spread of COVID-19.

\subsection{Instrumental Action}

Individuals take actions that lead to immediate problem solving, formulate steps and action plans and follow them, and strive to make things work.Subject TA and subject $N$ said that if they rarely find out the latest information about COVID-19, subject $R$ said that if he often searches for the latest information about COVID-19, subject A said if he did not find out information about COVID-19 because the television media had broadcast news, while for TR and RI subjects, they prefer not to watch news because watching 
news will only add to their thoughts. The TA subject said that if he took a lesson from this incident by getting closer to Allah and increasing his practice, subjects $R, T R, R I$, $A$ and $\mathrm{N}$ took lessons from this COVID-19 by appreciating more time and being closer to family, and improving care (empathy and sympathy) for others in line with applicable health protocols.

Based on the description above, it can be seen that not all subjects are always looking for the latest information about COVID-19. Subjects R, TR, RI, A and N said the same thing, namely they took lessons from COVID-19 by becoming closer to their family and for the subject of TA, he said that if he got closer to Allah and increased his practice of worship.This is in line with research conducted by (Muslim, 2020), which states that if the large amount of news related to the COVID-19 pandemic which is often unclear the source makes workers increasingly worried about carrying out activities outside the home, while the necessities of life and the economic pressure of the family require activities outside the home. This condition will cause conflict. Anxiety combined with conflict will exacerbate the stress on one's psyche. This is also in line with the narrative of the TR and RI subjects who conveyed that they prefer not to watch the news because watching the news will only increase their thoughts.

However, according to (Sudiro, A., \& Watimena, 2020), broadly speaking, media related to devices is the main choice for most people, this can be used by policy makers as a media for health promotion (promkes) and health education (penkes) in the community massively.. So that promotive and preventive efforts can run. This is in line with the actions taken by subject $A$, where he is always looking for the latest information about COVID-19, because this will increase knowledge regarding what should and should not be done in a pandemic like this.(Purnama, 2017) said that if religion has an important role in managing stress, religion can provide individuals with direction / guidance, support, and hope, as well as emotional support. Through prayer, rituals and religious beliefs can help a person in coping when experiencing stress in life, because of hope and comfort. This is in line with the narrative of the TA subject which states that during this pandemic, he is closer to Allah and increases his practice of worship.This was also added by research conducted by (Saputra, 2020)which said that good resilience ability in facing the COVID-19 pandemic by remaining optimistic, positive, taking preventive steps, following instructions and responding patiently by submitting everything to Allah after making efforts (Effort). 


\subsection{Negotiation}

Negotiation includes efforts to solve problems aimed at other people who are involved in the problem situation that is being experienced, such as attempts to change other people's thinking, bargaining or compromising to get something positive from the situation, and expressing anger at the right person.

Subjects A, N, TR, RI are individuals who actively inform their family members about complying with health protocols, such as wearing masks when they are outside the home. Meanwhile, subject $A$ and TA tended to be more passive in reminding others about the health protocol because the TA subjects thought that it was their personal responsibility and subject $A$ said that they rarely left the house. The six subjects have similarities in maintaining body immunity during the pandemic by adopting a healthy lifestyle, exercising, sunbathing, getting enough sleep, eating fruits and vegetables and the most important thing is to stay happy to avoid stress. The six subjects have various kinds of activities to fill their spare time so that they can remain productive at home. Just as subject $A$ fills his daily activities by studying online, watching television and also playing gadgets, subject $\mathrm{N}$ fills his spare time to stay productive by trying various kinds of new recipes, subject TR starts a new business, namely selling drinks and RI subject who fills in spare time by doing the best possible college assignments in order to stay productive.Based on the description above, it can be seen if the way the subjects remind others about health protocols is different, filling their activities and spare time to be productive in different ways. However, the six subjects had the same view regarding a healthy lifestyle in order to maintain immunity amid the COVID-19 pandemic.

This is in line with research conducted by (Aufar \& Raharjo, 2020) in which body relaxation can help a person to stay relaxed and stay active in maintaining health. Relaxation is an activity to relax the muscles in the body which is useful for reducing the tension felt by the body (Sari \& Murtini, 2015). The process of this relaxation activity holds firmly to regulating breathing and suggestions in order to feel calm and relieve anxiety (Aufar \& Raharjo, 2020). According to Utami[23], here are some of the benefits obtained from reflection, including: 1) helping someone to be more able to avoid doing things that are excessive due to stress; 2) less problems arising from headaches, high blood pressure, insomnia and other bad behavior; 3) reduce anxiety and show a positive psychological effect on a person; 4) increase enthusiasm in carrying out activities; and 5) improving interpersonal relationships (Marshall, Dunstan, \& Bartik, 2020).

The internet can be used for treatment and restore daily anxiety (Peynenburg, Mehta, \& Hadjistavropoulos, 2020), but caution is still needed considering the excessive time 
spent on COVID-19 news on social media given the infodemic and emotional transmission through networks online. Online platforms can be used to monitor mental health in pandemic victims. This is as stated by subject $A$, where he fills his daily activities by playing gadgets. Playing gadgets can indeed help fill spare time as long as they are not overused and do not seek negative information related to pandemics that can affect our mental health.

\section{Conclusion}

Based on the description of the previous data analysis, the researchers concluded that the six subjects had similarities in terms of protecting themselves from COVID-19 with health protocols, such as always wearing a mask, carrying a hand sanitizer wherever they went. Subject A said that he would not travel if it was not an urgent matter. The six subjects had similarities in terms of protecting themselves from COVID-19 by consciously always being more careful in maintaining their distance, and washing their hands using soap and running water that had been provided in every place they would enter or when they wanted to enter the house. These precautions are taken to avoid exposure to COVID-19 and help to break the chain of spread of COVID-19.

As a media for health promotion (promkes) and health education (penkes) in the community massively. So that promotive and preventive efforts can run. Not all of the six subjects always looked for the latest information about COVID-19. TR and RI subjects conveyed that they prefer not to watch news because watching news will only add to their thoughts. This is in line with the actions taken by subject $A$, where he is always looking for the latest information about COVID-19, because this will increase knowledge regarding what should and should not be done in a pandemic like this.

Through prayer, rituals and religious beliefs can help a person in coping when experiencing stress in life, because of hope and comfort. This is in line with the narrative of the TA subject which states that during this pandemic, he is closer to Allah and increases his practice of worship. Good resilience ability in facing the COVID-19 pandemic by remaining optimistic, positive, taking preventive steps, following instructions and responding patiently by submitting everything to God after doing business (Ikhtiar).

The six subjects had different ways of reminding others about health protocols. The six subjects have the same view regarding a healthy lifestyle in order to maintain immunity amid the COVID-19 pandemic. Such as maintaining body immunity during the pandemic by adopting a healthy lifestyle, exercising, sunbathing, getting enough sleep, eating fruits and vegetables and the most important thing is to stay happy to 
avoid stress. The six subjects have various kinds of activities to fill their spare time so that they can remain productive at home. Just as subject $A$ fills his daily activities by studying online, watching television and also playing gadgets, subject $\mathrm{N}$ fills his spare time to stay productive by trying various new recipes, subject TR starts a new business, namely selling. drinks and RI subjects who fill their spare time by doing their best college assignments to stay productive.

Subjects $A, N, T R, R$ are individuals who actively inform their family members about complying with health protocols, such as wearing masks when they are outside the home. Meanwhile, subject $A$ and TA tended to be more passive in reminding others about the health protocol because the TA subjects thought that it was their personal responsibility and subject $A$ said that they rarely left the house.

\section{Recommendation}

Based on the conclusion above, we recommend that :

1. It is hoped that students will be able to cope with the problems that occur during the Covid-19 pandemic by always applying health protocols.

2. Furthermore, researchers can conduct research with a theme similar to this research so that generalizations can be made.

3. Acknowledgment: we would like to thank Ahmad Dahlan University for the support and facilitation of our research.

\section{References}

[1] Aebi, M., et al. (2014). Problem Coping Skills, Psychosocial Adversities and Mental Health Problems in Children and Adolescents as Predictors of Criminal Outcomes in Young Adulthood. European Child and Adolescent Psychiatry, vol. 23, issue 5, pp. 283-293, https://doi.org/10.1007/s00787-013-0458-y.

[2] Ainamani, H. E., Gumisiriza, N. and Rukundo, G. Z. (2020). Mental Health Problems Related to COVID-19: A Call for Psychosocial Interventions in Uganda. Vol. 12, issue 7, pp. 809-811.

[3] Aufar, A. F. and Raharjo, S. T. (2020). Kegiatan Relaksasi Sebagai Coping Stress Di Masa Pandemi Covid-19. Jurnal Kolaborasi Resolusi Konflik, vol. 2, issue 2, p. 157, https://doi.org/10.24198/jkrk.v2i2.29126. 
[4] Banerjee, D. and Bhattacharya, P. (2020). 'Pandemonium of the Pandemic': Impact of COVID-19 in India, Focus on Mental Health. Psychological Trauma: Theory, Research, Practice, and Policy, vol. 12, issue 6, pp. 588-592, https://doi.org/10.1037/ tra0000799.

[5] Beam, C. R. and Kim, A. J. (2020). Psychological Sequelae of Social Isolation and Loneliness Might Be a Larger Problem in Young Adults Than Older Adults. Vol. 12, pp. 58-60.

[6] Bell, D. J., et al. (2020). Health Service Psychology Education and Training in the Time of COVID-19: Challenges and Opportunities. American Psychologist, vol. 75, issue 7, pp. 919-932, https://doi.org/10.1037/amp0000673.

[7] Bryant, D. J., Oo, M. and Damian, A. J. (2020). The Rise of Adverse Childhood Experiences During the COVID-19 Pandemic. Psychological Trauma: Theory, Research, Practice, and Policy, vol. 12, pp. 193-194, https://doi.org/10.1037/ tra0000711.

[8] Herdiansyah, H. (2015). No Title. Depok: PT. Rajadrafindo Persada.

[9] Jaspal, R. and Nerlich, B. (2020). Social Representations, Identity Threat, and Coping Amid COVID-19. Psychological Trauma: Theory, Research, Practice, and Policy, vol. 12, pp. 249-251, https://doi.org/10.1037/tra0000773.

[10] Johnson, M. T., et al. (2020). Psychological Trauma: Mitigating Social and Economic Sources of Trauma: The Need for Universal Basic Income During the Coronavirus Pandemic. Vol. 12, pp. 191-192.

[11] Lovell, B. and Gaszka, S. (2018). Problem-Focused Coping Mediates the Effect of Subclinical Trauma Symptoms in Returning Service Members on Psychological Distress in their Civilian Partners. Traumatology, vol. 24, issue 4, pp. 288-292, https://doi.org/10.1037/trm0000150.

[12] Marshall, J. M., Dunstan, D. A. and Bartik, W. (2020). The Role of Digital Mental Health Resources to Treat Trauma Symptoms in Australia During COVID-19. Psychological Trauma: Theory, Research, Practice, and Policy, vol.12, pp. 269-271, https://doi.org/ 10.1037/tra0000627.

[13] Mohsin, A. K. M., Hongzhen, L., Sume, A. H. and Hussain, M. H. (2020). Analysis of the Causes of Moral Injury in the Outbreak of 2019-nCoV. Psychological Trauma: Theory, Research, Practice, and Policy, vol. 12, pp. 162-164, https://doi.org/10.1037/ tra0000720.

[14] Muslim, M. (2020). Stress Management during the COVID-19 Pandemic. ESSENCE: Journal of Business Management, pp. 192-201. 
[15] Peynenburg, V. A., Mehta, S. and Hadjistavropoulos, H. D. (2020). Postsecondary Student Perceptions and Preferences for the Treatment of Depression and Anxiety: Comparison of Internet-Delivered Cognitive Behaviour Therapy to Face-To-Face Cognitive Behaviour Therapy and Medication. Canadian Journal of Behavioural Science, vol. 52, issue 3, pp. 220-230, https://doi.org/10.1037/cbs0000165.

[16] Purnama, R. (2017). Stress Resolution through Spiritual Coping. Al-Adyan, pp. 70-83.

[17] Reife, I., Duffy, S. and Grant, K. E. (2020). The Impact of Social Support on Adolescent Coping in the Context of Urban Poverty. Vol. 26, issue 2, pp. 200-214.

[18] Saputra, T. U. (2020). Bentuk Kecemasan dan Resiliensi Mahasiswa Pascasarjana Aceh-Yogyakarta dalam Menghadapi Pandemi COVID-19. Jurnal Bimbingan Dan Konseling Ar-Rahman, vol. 6, pp. 55-61.

[19] Sari, H. F. and Murtini, M. (2015). Relaksasi Untuk Mengurangi Stres Pada Penderita Hipertensi Esensial. Humanitas, vol. 12, issue 1, p. 12, https://doi.org/10.26555/ humanitas.v12i1.3823.

[20] Semaraputri, S. A. K. T. and Rustika, I. (2018). The Role of Problem Focused Coping and Self-Concept on Self-Adjustment in Late Adolescents who Become Management of Student Organizations at the Faculty of Medicine, University of Udayana. Journal of Psychology Udayana, pp. 35-47.

[21] Sudiro, A. and Watimena, L. (2020). Attitudes and Behaviors of Indonesian Society Towards the Corona Virus Pandemic (COVID-19) in Indonesia. Journal of Medicine and Health: Scientific Publications of the Faculty of Medicine Sriwijaya University, pp. 1-6.

[22] Taylor, S. E. and Stanton, A. L. (2007). Coping Resources, Coping Processes, and Mental Health. Annual Review of Clinical Psychology, vol. 3, pp. 377-401, https: //doi.org/10.1146/annurev.clinpsy.3.022806.091520.

[23] Trougakos, J. P., Chawla, N. and McCarthy, J. M. (2020). Working in a Pandemic: Exploring the Impact of COVID-19 Health Anxiety on Work, Family, and Health Outcomes. Journal of Applied Psychology, https://doi.org/10.1037/apl0000739.

[24] Umucu, E. and Lee, B. (2020). Examining the Impact of COVID-19 on Stress and Coping Strategies in Individuals with Disabilities and Chronic Conditions. Rehabilitation Psychology, vol. 65, issue 3, pp. 193-198, https://doi.org/10.1037/ rep0000328.

[25] Wong, J. Y. H., et al. (2016). Problem-Focused Coping Mediates the Impact of Intimate Partner Violence on Mental Health among Chinese Women. Psychology of Violence, vol. 6, issue 2, pp. 313-322, https://doi.org/10.1037/a0039496. 
[26] Yonatan-Leus, R., Shefler, G. and Tishby, O. (2020). Do Positive Features of Mental Health Change Together with Symptoms and do they Predict Each Other? Psychotherapy, vol. 57, issue 3, pp. 391-399, https://doi.org/10.1037/pst0000280. 